\title{
PELATIHAN PENULISAN ARTIKEL ILMIAH BERBASIS PENELITIAN TINDAKAN KELAS PADA GURU SMP
}

\author{
Oleh: \\ Putri Kumala Dewi ${ }^{1}$, Maulfi Syaiful Rizal², Dany Ardhian³, Vanda Hardinata ${ }^{4}$, Yulina Dwi Lestari5 \\ 1,2,3,4,5 Universitas Brawijaya
1danyardhian@ub.ac.id
}

Abstrak

Menurut Permendikbud No. 18 Tahun 2007 tentang Sertifikasi Guru dalam Jabatan, guru harus selalu berupaya meningkatkan kompetensi profesionalnya. Salah satunya dengan karya pengembangan profesi berupa artikel ilmiah. Artikel ilmiah menjadi syarat wajib guru dengan pangkat III/b dan kenaikan pangkat guru dari golongan IV/a ke IV/b. Untuk itu, keterampilan menulis artikel ilmiah menjadi penting bagi guru saat ini. Pelatihan ini dilaksanakan pada tanggal 8 dan 15 Agustus 2015 pada guru SMP Shalahuddin Malang. Pelatihan tahap I difokuskan pada kegiatan interogasi yaitu pemahaman kaidah penulisan artikel ilmiah dan kegiatan elaboratif dengan fokus mengembangkan ide menulis artikel ilmiah berbasis PTK. Selanjutnya pada tahap II, pelatihan difokuskan ke praktik penulisan dan penyuntingan artikel ilmiah berbasis PTK. Tujuan dari kegiatan ini adalah untuk meningkatkan keterampilan menulis artikel ilmiah berbasis penelitian tindakan kelas, meliputi tahap 1) interogasi, 2) elaboratif, 3) penulisan, dan 4) penyuntingan, baik dari segi proses maupun hasil. Hasil dari pelatihan ini adalah guru telah mahir menulis artikel ilmiah berbasis PTK pada bagian judul, abstrak, kata kunci, hasil penelitian, simpulan, saran, dan daftar rujukan. Namun, para guru masih mengalami hambatan pada bagian pendahuluan, metode, dan pembahasan.

Kata Kunci: Penulisan Artikel, Penelitian Tindakan Kelas, Guru SMP

\begin{abstract}
According Permendikbud Number 18 year 2007 on Teachers Certification, teachers should always seek to improve their professional competence One of them by making scientific articles. Scientific articles became a mandatory requirement of teachers with the rank III / b and promotion of teachers from IV / A to IV / b. To that end, the skill of writing a scientific article to be important for teachers. This training took place on June 8 and August 15, 2015 at the Junior High School teacher in Shalahuddin Malang. Training Phase I focused on the activities of the interrogation which is understanding the rules of writing scientific articles and elaborative activities with a focus on developing the idea of writing a scientific article based PTK. Furthermore, in the second stage, focused training to practice writing and editing scientific articles based PTK. The purpose of this activity is as follows: improve the skills of writing scientific articles based action research at the stage of interrogation, elaborative, writing, and editing, both in terms of process and outcome. The results of this training are already proficient teacher writing scientific articles PTK based on the title, abstract, keywords, research results, conclusions, recommendations, and a list of references. However, teachers are still obstacles in the introduction, methods, and discussion.
\end{abstract}

Keywords: Writing article, classroom action research, junior high school teachers

\section{PENDAHULUAN}

Menulis artikel ilmiah merupakan salah satu kompetensi yang harus dikuasai guru agar bisa dikatakan profesional. Dengan mulai diberlakukannya program sertifikasi, guru terus dituntut untuk meningkatkan kompetensi profesionalnya. Menurut Permendikbud No. 18 Tahun 2007 tentang Sertifikasi Guru dalam Jabatan dinyatakan bahwa salah satu komponen penilaian sertifikasi guru adalah karya pengembangan profesi. Karya pengembangan profesi yang dimaksud di antaranya dipenuhi dengan melakukan Penelitian Tindakan Kelas (PTK) sebagai upaya evaluasi dan perbaikan mutu pembelajaran serta menulis artikel ilmiah untuk jurnal. PTK merupakan usaha evaluasi pengajaran dan pembelajaran yang dilakukan di dalam kelas. Hasil PTK tersebut kemudian dipublikasikan jurnal, agar guru-guru yang lain dapat belajar dari permasalahan yang ditemui. Dua kewajiban profesional inilah kemudian memunculkan permasalahan baru bagi guru. 
Permasalahan tentang banyaknya guru yang masih merasa terbebani dengan kegiatan penelitian tindakan kelas dan menulis artikel ilmiah terjadi di SMP Shalahuddin Malang. Sebanyak 29 guru, 95\% di antaranya sudah pernah dikirim untuk mengikuti workshop tentang PTK. Hal ini sesuai dengan prioritas program SMP Shalahuddin yang ingin mengefektifkan KBM serta meningkatkan mutu sekolah. Bahkan, dalam forum MGMP pun, guru banyak bertukar pengetahuan tentang PTK. Namun, untuk menyusun hasil PTK menjadi artikel ilmiah, terutama yang siap diterbitkan di jurnal, $90 \%$ guru masih merasa belum mahir dan akhirnya kurang termotivasi dalam menulis artikel ilmiah. Akhirnya banyak guru yang mencari jasa penulisan artikel ilmiah. Selain itu, jumlah jurnal bereputasi di Indonesia juga sangat terbatas. Hal ini semakin menyulitkan dan menurunkan motivasi guru untuk mengirimkan artikelnya dalam jurnal.

Model interogasi elaboratif diterapkan dalam pelatihan penulisan artikel ilmiah berbasis PTK sebagai alternatif solusi untuk mengatasi kurangnya pengetahuan guru tentang artikel ilmiah, kurang terampilnya guru dalam mencari dan mengembangkan ide, serta kurangnya motivasi guru. Menurut Buehl (2001) dan Ginnis (2008) secara umum, prinsip model interogasi elaboratif meliputi dua tahap kegiatan di antaranya tahap interogasi dan elaboratif. Tahap interogasi meliputi kegiatan mengkaji artikel ilmiah dari segi sistematika, komponen isi, dan aspek kebahasaannya dengan menggunakan "peta pemburu".

Selanjutnya tahap elaboratif meliputi kegiatan mengkaji kembali PTK yang telah dilakukan dari segi permasalahan aktual yang dibahas dalam PTK, hubungan sebab akibat dalam permasalahan aktual, mengkaji kembali asumsi, alternatif solusi, dan hasilnya dengan menggunakan "peta pencari fakta". Lalu guru menuliskannya dalam bentuk artikel ilmiah dan menyuntingnya.

Tujuan dari kegiatan ini sebagai berikut: meningkatkan keterampilan menulis artikel ilmiah berbasis penelitian tindakan kelas pada guru SMP Shalahuddin Malang pada tahap interogasi, elaboratif, penulisan, dan penyuntingan, baik dari segi proses maupun hasil.

Menulis karya ilmiah merupakan aktivitas yang tidak dapat dihindarkan dari rangkaian aktivitas guru saat ini. Sebagai bagian dari upaya peningkatan mutu pembelajaran dan kompetensi profesional, guru harus memiliki kemahiran dalam menulis artikel ilmiah, terutama yang siap diterbitkan di jurnal.

Menulis artikel ilmiah adalah menulis suatu karya tulis nonfiksi yang di dalamnya berisi gagasan, pemecahan masalah, pemikiran konseptual, dan hasil pengamatan yang selanjutnya disusun secara sistematis sesuai dengan kaidah (Supriyadi, 2013). Sementara itu, menurut Suyanto dan Jihad (2014:34) menulis artikel ilmiah adalah menulis hasil pengkajian sistematis berdasarkan metode ilmiah untuk mendapatkan jawaban ilmiah terhadap suatu permasalahan dan diterbitkan dalam jurnal. Sementara menurut Maimunah (2007:91) artikel ilmiah dirancang untuk dimuat dalam jurnal atau buku kumpulan artikel. Dari tiga pendapat ini, dapat dipahami bahwa konsep mendasar dari kegiatan menulis artikel ilmiah adalah menulis suatu hasil pengamatan terhadap permasalahan aktual di masyarakat didasarkan pada alur berpikir ilmiah dan metode ilmiah yang sistematis dan konseptual, didukung oleh data yang dapat dibuktikan kebenarannya, diperoleh jawaban ilmiah terhadap masalah yang dihadapi, dan disiapkan untuk dimuat dalam jurnal.

Secara umum, manfaat menulis artikel ilmiah bagi guru adalah meningkatkan kompetensi profesionalitasnya dan meningkatkan mutu pembelajaran. Secara khusus, manfaat yang diperoleh adalah meningkatkan kemahiran guru dalam merumuskan, menambahkan, merevisi, dan akhirnya sampai pada bentuk final tulisan yang siap dipublikasikan.

Bagaimana pun juga menulis artikel ilmiah terlebih untuk kepentingan publikasi merupakan sebuah proses yang membutuhkan tahapan dan latihan yang intensif. Hal itu disebabkan oleh artikel ilmiah memiliki kriteria-kriteria yang berbeda dengan jenis tulisan yang lain. Kriteria-kriteria tersebut antara lain: berangkat dari kajian terhadap masalah, adanya fakta empiris, bebas dari prasangka, menggunakan prinsipprinsip analisis, menggunakan hipotesis, menggunakan ukuran objektif, serta menggunakan teknik kuantitatif/kualitatif. Selain itu, untuk memenuhi artikel ilmiah dengan kualifikasi baik, guru harus memiliki knowledge, courage, experience, and inspiration (Suyanto dan Jihad, 2014:28).

PTK adalah penelitian yang dilakukan guru disebabkan oleh adanya masalah dalam pembelajaran di kelas yang kemudian berdampak pada kurangnya kemampuan 
siswa. Guru selanjutnya menerapkan tindakan-tindakan tertentu pada setiap siklus untuk memperbaiki atau meningkatkan praktik-praktik pembelajaran di kelas secara lebih profesional (Suroso, 2007:20). Manfaat PTK bagi guru adalah memperbaiki atau meningkatkan praktik-praktik pembelajaran di kelas secara lebih profesional melalui penerapan tindakan-tindakan pada setiap siklus (Suroso, 2007:20).

Ada empat kegiatan yang dilaksanakan dalam setiap siklus PTK di antaranya perencanaan, pelaksanaan, pengamatan, dan refleksi (Iskandar, 2009:48). Dalam setiap siklus, peneliti terlibat langsung dalam setiap tahap penelitian dan bekerja sama dengan siswa untuk memeroleh pandangan serta memiliki kewenangan dalam menentukan pelaksanaan dan berhasil tidaknya penelitian.

Model interogasi elaboratif adalah model memahami tata cara penulisan artikel ilmiah dan penggalian idenya dengan cara mengajak guru mengikuti dua tahap kegiatan di antaranya kegiatan interogasi dan elaboratif. Tujuan model ini adalah guru dapat memahami kaidah artikel ilmiah dan dapat mengaktifkan pemahamannya terhadap PTK yang telah dilakukan untuk dituliskan dalam bentuk artikel ilmiah. Menurut Buehl (2001) dan Ginnis (2008) secara rinci, prinsip model interogasi elaboratif meliputi dua tahap kegiatan sebagai berikut.

\section{Tahap interogasi}

Tahap interogasi adalah tahap mengkaji artikel ilmiah dari segi sistematika, komponen isi, dan aspek kebahasaannya. Cara yang digunakan adalah dengan menggunakan "peta pemburu". Dalam peta tersebut, terdapat sejumlah alur kegiatan yang harus dikerjakan guru. Pertama, guru diberikan contoh artikel ilmiah dengan kualifikasi baik. Kedua, guru mengkaji mengapa artikel tersebut berkualifikasi baik. Ketiga, guru mengidentifikasi artikel ilmiah dari segi sistematika, komponen isi, dan aspek kebahasaannya. Keempat, menyusun simpulan. Hasil akhir dari tahap interogasi ini adalah guru memahami kaidah artikel ilmiah.

\section{Tahap elaboratif}

Tahap elaboratif adalah tahap pengembangan ide menulis karya ilmiah. Dengan menggunakan "peta pencari fakta", guru diajak mengikuti beberapa alur kegiatan. Pertama, guru mengkaji kembali PTK yang telah dilakukan dari segi permasalahan aktual yang dibahas dalam PTK dan hubungan sebab akibat dalam permasalahan aktual.
Kedua, guru mengkaji kembali asumsi, alternatif solusi, dan hasilnya. Hasil akhir dari tahap elaboratif ini adalah guru memiliki draf artikel ilmiah. Selanjutnya guru mengembangkan draf menjadi artikel ilmiah dan menyuntingnya. Jadi, tahap elaboratif ini dapat diterapkan ketika setiap guru telah menguasai isi PTK yang ditulisnya. Untuk itu, sebelum pelaksanaan pelatihan, pada saat sosialisasi tim meminta guru untuk menyiapkan dan mempelajari PTK yang ditulisnya. Untuk guru yang belum melakukan PTK, tim menyiapkan draf PTK untuk guru tersebut.

\section{METODE PELAKSANAAN}

\section{Kerangka Pemecahan Masalah}

Berdasarkan hasil wawancara dengan Kepala Sekolah dan beberapa guru di SMP Shalahuddin diketahui bahwa guru kurang memiliki pengetahuan tentang artikel ilmiah, kualifikasinya, serta kurang terbiasa menulis artikel ilmiah yang berakibat pada ketidaksistematisan alur berpikir dan kekurangmahiran menggunakan bahasa Indonesia ilmiah. Kendala-kendala tersebut menurunkan motivasi guru untuk menulis artikel ilmiah.

\section{Realisasi Pemecahan Masalah}

Kegiatan pengabdian masyarakat ini direalisasikan dalam bentuk pelatihan penulisan artikel ilmiah berbasis PTK melalui metode interogasi elaboratif. Kegiatan dilaksanakan dalam dua pertemuan di antaranya tanggal 8 dan 15 Agustus 2015. Kegiatan tahap pertama yaitu tanggal 8 Agustus 2015 difokuskan pada tahap interogasi (pemahaman kaidah artikel ilmiah) dan elaboratif (pengembangan ide menulis artikel ilmiah berbasis PTK). Pada tahap pertama ini juga diberikan materi suplemen berupa urgensi penulisan artikel ilmiah oleh guru dan kriteria kelayakan artikel ilmiah. Pelatihan tahap kedua yaitu tanggal 15 Agustus 2015 difokuskan pada praktik menulis dan menyunting artikel ilmiah berbasis PTK.

\section{Khalayak Sasaran}

Kegiatan pelatihan ini ditujukan bagi guru SMP Shalahuddin berjumlah 29 orang.

\section{Metode yang Digunakan \\ Metode yang digunakan dalam pengabdian masyarakat ini sebagai berikut.}


1. Observasi dan wawancara yang berguna untuk mengetahui problematika yang guru dalam penulisan artikel ilmiah berbasis PTK.

2. Sosialisasi yang bertujuan untuk mempublikasikan kegiatan pengabdian kepada guru di sekolah.

3. Penyusunan modul pelatihan.

4. Pelatihan yang bertujuan untuk meningkatkan keterampilan guru dalam menulis artikel ilmiah berbasis PTK. Pelatihan direncanakan dilaksanakan dalam dua kali pertemuan. Pertemuan pertama difokuskan pada tahap interogasi dan elaborasi. Pertemuan kedua, difokuskan pada tahap penulisan dan penyuntingan.

5. Refleksi dilakukan pada setiap akhir pelaksanaan pelatihan untuk mengetahui hasil pelatihan yang ditemukan tim pengabdian selama mendampingi guru berlatih menulis dan menyunting artikel ilmiah

6. Penyebaran kuesioner kepada peserta pelatihan untuk mengetahui proses pelaksanaan pelatihan.

\section{HASIL DAN PEMBAHASAN}

\section{Proses Pelatihan Penulisan Artikel IImiah Berbasis Penelitian Tindakan Kelas pada Guru SMP Shalahuddin Malang pada Tahap Interogasi}

Pada kegiatan ini, pemateri memulai kegiatan dengan meminta guru membaca contoh artikel ilmiah terlebih dahulu. Artikel ilmiah yang dibagikan oleh tim kepada para guru berjudul "Peningkatan Keterampilan Menulis Cerpen melalui Strategi Copy the Master dan Media Audiovisual pada Siswa Kelas IX SMPN 2 Dampit" Lalu para guru diminta untuk memecahkan empat teka-teki artikel ilmiah dalam "peta pemburu". Teka-teki tersebut berisi identifikasi umum alasan artikel dikategorikan baik, sistematika, komponen isi, dan ciri bahasa artikel ilmiah. Setelah guru menyelesaikan keempat teka- teki tersebut, guru akan mendapatkan reward berupa jawaban setiap teka-teki dari tim.

\section{Hasil Pelatihan Penulisan Artikel IImiah Berbasis Penelitian Tindakan Kelas pada Guru SMP Shalahuddin Malang pada Tahap Interogasi}

Hasil yang diperoleh dari tahap interogasi ini dirinci sebagai berikut.

\section{Identifikasi umum}

Dari peserta pelatihan, 16 guru menjawab bahwa artikel ilmiah baik karena telah memenuhi sistematika artikel yang lengkap, komponen isi lengkap, mempunyai tujuan dan permasalahan yang jelas, penyajian data sesuai dengan metode penelitian dan prosedur PTK, serta menggunakan bahasa Indonesia ragam ilmiah. Sementara itu, 8 guru tidak sepenuhnya setuju jika contoh artikel dikategorikan baik karena judulnya terlalu panjang atau melebihi 15 kata, dalam judul menyebutkan dengan detail instansi yang diteliti, tidak ada catatan kaki yang menunjukkan instansi peneliti, kata kunci lebih dari 5 kata.

\section{Identifikasi sistematika}

Ditinjau dari sistematikanya, seluruh guru menjawab bahwa artikel ilmiah yang dibaca sudah lengkap, runtut, dan menggambarkan alur PTK. Sistematika artikel ilmiah berbasis PTK dikatakan lengkap jika terdiri atas judul, nama penulis dan instansinya, abstrak, kata kunci, pendahuluan, metode, hasil, pembahasan, simpulan, saran, dan daftar rujukan.

\section{Identifikasi komponen isi}

Pada kegiatan mengidentifikasi komponen isi setiap sistematika artikel ilmiah berbasis PTK, 26 guru mampu mengidentifikasi setiap komponen isi dalam sistematika artikel ilmiah berbasis PTK. Berikut disajikan dua hasil identifikasi guru terhadap komponen isi artikel ilmiah berbasis PTK.

Tabel 1. Hasil Identifikasi Komponen Isi Artikel IImiah Berbasis PTK

\begin{tabular}{lll}
\hline \multicolumn{2}{c}{ Hasil Analisis I } & \multicolumn{2}{c}{ Hasil Analisis II } \\
\hline Judul : tidak perlu menulis dengan detail & Judul terdapat 15 kata, sudah sesuai dengan \\
lokasi penelitian sehingga memenuhi & $\begin{array}{l}\text { aturan yang baik, informatif, dan memuat } \\
\text { variabel yang menggambarkan masalah yang } \\
\text { kriteria maksimal 15 kata }\end{array}$ & diteliti \\
\hline Nama penulis sudah sesuai & $\begin{array}{l}\text { Nama penulis ditulis sesuai aturan yaitu tanpa } \\
\text { gelar dan nama lembaga asal penulis ditulis di }\end{array}$ \\
& catatan kaki di halaman pertama \\
\hline Abstrak terlalu panjang karena melebihi 75 & Abstrak sudah memuat masalah, tujuan, \\
\hline
\end{tabular}




\begin{tabular}{ll}
\hline \multicolumn{1}{c}{ Hasil Analisis I } & \multicolumn{1}{c}{ Hasil Analisis II } \\
\hline kata & $\begin{array}{l}\text { prosedur, dan hasil penelitian. Namun, } \\
\text { panjangnya 84 kata. }\end{array}$ \\
\hline Kata kunci sudah sesuai & $\begin{array}{l}\text { Kata kunci sudah menggambarkan daerah } \\
\text { masalah yang diteliti dan jumlahnya tidak lebih } \\
\text { dari 5 kata sehingga sesuai dengan kriteria }\end{array}$ \\
\hline $\begin{array}{l}\text { Pendahuluan kurang lengkap, terutama di } \\
\text { bagian tujuan karena belum ada manfaat }\end{array}$ & $\begin{array}{l}\text { Pendahuluan tidak diberi judul atau langsung } \\
\text { penelitian bagi siswa setelah kata kunci, sudah } \\
\text { menggambarkan latar belakang, masalah dan } \\
\text { wawasan rencana pemecahanan masalah, } \\
\text { terdapat rumusan tujuan dan manaan } \\
\text { penelitian yaitu membuka wawasan untuk } \\
\text { mencari strategi alternatif guna meningkatkan } \\
\text { pembelajaran menulis cerpen }\end{array}$ \\
\hline
\end{tabular}

Metode penelitian masih kurang sempurna Metode artikel ilmiah sudah berisi rancangan karena hanya menggunakan 2 siklus penelitian yaitu PTK, data, sumber data sudah dicantumkan rendahnya nilai menulis cerpen, prosedur pengumpulan data jelas yaitu observasi dan tes hasil belajar, analisisnya dilakukan dengan tiga tahap yaitu reduksi data, penyajian data, serta pengambilan simpulan serta pengecekan keabsahan data melalui 3 cara sudah jelas

Hasil penelitian sudah melalui tes dan ada Hasil penelitian sudah berisi data yang nilainya

Pembahasan berisi jawaban rumusan
masalah, ketercapaiannya, dan sudah
sesuai dengan ketentuan PTK
mendukung fokus penelitian begitu pula analisis datanya

Pembahasan sudah dapat menjawab rumusan masalah yaitu penerapan metode/strategi copy the master telah meningkatkan kemampuan menulis cerpen, ketercapaian sudah ditunjukkan oleh tabel capaian hasil belajar prasiklus, siklus I, dan siklus II

Simpulan dan saran sudah berisi pokokpokok pikiran tentang esensi hasil dan pembahasan. Selain itu, isinya supaya guru yang lain melakukan pembelajaran sesuai dengan yang telah dilakukan peneliti.

Simpulan sudah mengarah pada pokok-pokok pikiran tentang esensi hasil dan pembahasan yang intinya strategi copy the master telah mampu meningkatkan kemampuan menulis cerpen siswa kelas IX SMPN 2 Dampit. Saran sudah berisi tindakan praktis, sudah dijelaskan, namun saran pengembangan teoretis dan penelitian lanjutan belum disarankan

Daftar rujukan sudah lengkap Daftar rujukan sudah sesuai dengan aturan dan sudah lengkap sesuai dengan kutipan

Simpulan isi secara keseluruhan adalah isi Gutomo Wibi Ananggih, S.Pd antarbagian artikel memiliki kesatuan ide/gagasan (Nurini, S.Pd)

Dari Tabel 1 di atas dapat diketahui bahwa kedua guru telah mengidentifikasi setiap komponen isi dalam artikel ilmiah berbasis PTK dengan sangat rinci dan sesuai dengan laborat.

\section{Identifikasi labo bahasa}

Hasil identifikasi 24 guru peserta pelatihan menyatakan artikel ilmiah berbasis PTK menggunakan bahasa Indonesia ragam ilmiah. Ciri-cirinya menggunaan kalimat efektif, lugas, jelas, dan sesuai dengan EYD.

\section{Proses Pelatihan Penulisan Artikel IImiah Berbasis Penelitian Tindakan Kelas pada Guru SMP Shalahuddin Malang pada Tahap Elaboratif}

Pada tahap ini, guru diarahkan untuk mengembangkan ide untuk menulis artikel ilmiah dari PTK yang pernah dibuat. Alat yang digunakan oleh tim adalah dengan 
menggunakan "peta pencari fakta" (Modul Pelatihan, 2015:18) dengan langkah-langkah sebagai berikut:

1. pemateri membangun laborat dan pemahaman bersama tentang konsep PTK.

2. para guru diminta untuk membaca kembali PTK yang telah dibuat.

3. Ketiga, guru mengkaji kembali PTK dari segi permasalahan labor menggunakan identifikasi fakta 1.

4. guru diminta mengidentifikasi fakta 2 yang berkaitan dengan sebab akibat permasalahan labor dalam PTK

5. guru diminta untuk menuliskan asumsi PTK.

6. guru diminta menuliskan solusi berupa metode atau media yang digunakan untuk memperbaiki problematika pembelajaran.

7. guru diminta untuk menuliskan hasil penelitian PTK.

8. guru memiliki alur kerangka ide penulisan artikel ilmiah berbasis PTK. Alur tersebut tertuang dalam "peta pencari fakta" yang telah selesai diidentifikasi oleh guru.

Hasil pelatihan penulisan artikel ilmiah berbasis Penelitian Tindakan Kelas pada Guru SMP Shalahuddin Malang pada tahap elaborative dijelaskan secara detail, berikut ini.

Pada tahap mengidentifikasi permasalahan labor PTK, 24 guru tidak mengalami kendala. Akan tetapi, dari segi kelengkapan jawaban, 20 guru mengidentifikasi permasalahan labor dengan sangat detail, sedangkan 4 guru kurang detail. Berikut beberapa hasil identifikasi permasalahan labor oleh guru yang detail dan kurang detail.

\section{Hasil identifikasi permasalahan aktual secara detail}

1. Berdasarkan hasil tes awal, dapat diketahui bahwa sebagian besar hasil karangan siswa mendapatkan nilai kurang memuaskan dan di bawah KKM.

2. Siswa mengalami kesulitan ketika memulai menulis sesuatu, nada tulisan bergantung, dan tidak mengetahui tujuan menulis.

3. Tidak adanya pembangunan materi dan ide sebelum menulis sehingga tidak ada dimensi kontak emosi dan gagasan pribadi siswa terhadap cerita yang ditulisnya (Umi Faizah, S.Pd)

\section{Hasil identifikasi permasalahan aktual yang kurang detail}

Permasalahan labor yang ada adalah kemampuan menulis narasi (Susi

Mawarsari, S.Pd)

Dari kedua contoh hasil analisis di atas, tampak bahwa guru telah memahami permasalahan labor dalam PTK yang dibaca. Permasalahannya terletak pada ketidakmampuan siswa menggali dan mengembangkan ide dalam menulis narasi yang menyebabkan nilai mereka berada di bawah KKM. Namun, cara guru mengidentifikasi permasalahan labor ada yang dilakukan dengan detail dan kurang detail. Namun, dengan bimbingan tim, para guru memahami bahwa permasalahan labor dalam PTK dapat dijumpai di bagian latar belakang dan rumusan masalah. Untuk itu, bagian latar belakang PTK tidak seharusnya hanya berupa teori, tetapi langsung ke permasalahan konkret.

Pada kegiatan identifikasi fakta 2 yaitu identifikasi sebab akibat permasalahan labor, 18 guru menjawab dengan tepat dan rinci, sedangkan 6 lainnya kurang tepat. Berikut disajikan hasil identifikasi guru yang tepat dan kurang tepat.

\section{Hasil identifikasi sebab akibat permasalahan aktual yang tepat}

1. Siswa mengalami kesulitan ketika menulis narasi.

2. Siswa tidak mengetahui tujuan menulis (sekadar mengerjakan tugas dari guru) akibatnya cerita yang ditulis siswa kurang hidup (Dra. Sri Yuliani)

\section{Hasil identifikasi sebab akibat} permasalahan aktual yang kurang tepat

1. Sebab: anak tidak suka membaca

2. Akibat: anak tidak terampil menulis narasi (Tutik Mudjiati, S.Pd)

Dari kedua contoh hasil analisis di atas, tampak bahwa tidak semua guru memahami sebab akibat permasalahan labor dalam PTK yang dibaca. Ketidaktepatan tersebut disebabkan oleh kekurangpahaman guru terhadap sumber permasalahan dalam PTK.

Hasil identifikasi fakta 3 tentang asumsi PTK menunjukkan bahwa 21 guru mampu mengidentifikasi fakta dengan tepat, sedangkan 3 guru lainnya kurang tepat. Berikut disajikan hasil identifikasi fakta tentang asumsi PTK yang tepat dan kurang tepat. 


\section{Hasil identifikasi asumsi yang tepat}

Keterampilan menulis narasi dapat ditingkatkan dengan berbagai cara/metode (Dra. Sri Yuliani)

\section{Hasil identifikasi sebab akibat permasalahan aktual yang kurang tepat}

Meningkatnya kemampuan keterampilan siswa dalam menulis narasi (Becik Susiati, S.Pd)

Hasil identifikasi fakta 4 tentang solusi yang diterapkan dalam PTK menunjukkan 24 guru telah mampu menentukan solusi permasalahan berdasarkan analisis sumber masalah. Berikut ini disajikan hasil identifikasi guru terhadap fakta 4 tentang solusi tindakan PTK.

Identifikasi fakta 4: Menggunakan metode rekreasi imajinasi agar siswa mampu dan terampil dalam menulis narasi dengan cara mengembangkan imajinasi, mengkreasikan imajinasi, dan merekreasikan imajinasi (Becik Susiati, S.Pd)

Meningkatkan kemampuan siswa melalui metode menulis narasi dengan metode rekreasi imajinasi (Umi Faizah, S.Pd)

Dari dua hasil analisis di atas dapat diketahui bahwa tidak seorang guru pun yang belum memahami bahwa solusi PTK didasarkan pada hasil analisis terhadap sumber masalah. Hasil analisis di atas menunjukkan bahwa metode rekreasi imajinasi merupakan solusi untuk mengatasi masalah kekurangmampuan siswa dalam menulis narasi. Siswa kurang mampu menggali dan mengembangkan ide. Hal itu disebabkan oleh metode guru yang kurang mampu mengembangkan kemampuan siswa dalam menggali dan mengembangkan ide. Untuk itu, solusi untuk permasalahan tersebut berupa penerapan suatu metode yang dapat membantu siswa menggali dan mengembangkan ide.

Pada tahap mengidentifikasi fakta 5 yaitu tentang hasil penelitian, hasilnya adalah 24 guru dapat mengidentifikasi dengan tepat. Berikut ini beberapa hasil identifikasi guru terhadap hasil penelitian.

Dengan penerapan metode rekreasi imajinasi dalam pembelajaran menulis narasi terbukti dapat meningkatkan kemampuan siswa (Umi Faizah, S.Pd).

Melalui metode rekreasi imajinasi, siswa terampil dalam menulis narasi (Becik Susiati, S.Pd)

Dari kedua jawaban di atas tampak bahwa guru tidak mengalami kesulitan dalam mengidentifikasi hasil penelitian. Hasil penelitian mengacu pada rumusan masalah PTK.

Adapun hasil refleksi tim terhadap kegiatan pelatihan tahap pertama diketahui bahwa pada tahap mengidentifikasi kaidah artikel ilmiah berbasis PTK dengan menggunakan metode interogasi laborative, guru tidak mengalami kesulitan. Hanya para guru menjadi tidak percaya diri dengan PTK nya sendiri setelah mendapat penjelasan tentang seluk-beluk PTK. Akhirnya pada tahap laborative, para guru menggunakan contoh PTK yang disiapkan tim.

\section{Proses Pelatihan Penulisan Artikel IImiah Berbasis Penelitian Tindakan Kelas pada Guru SMP Shalahuddin Malang pada Tahap Penulisan}

Proses pelatihan penulisan artikel ilmiah berbasis Penelitian Tindakan Kelas pada Guru SMP Shalahuddin Malang melalui tiga tahapan.

1. para guru dipandu untuk menuliskan judul artikel ilmiah terlebih dahulu.

2. para guru diminta untuk menuliskan nama, asal instansi, abstrak, dan kata kunci.

3. tim memberikan kesempatan kepada para guru untuk menyusun pendahuluan, metode, hasil, pembahasan, simpulan, saran, dan daftar rujukan.

Hasil pelatihan penulisan artikel ilmiah berbasis Penelitian Tindakan Kelas pada Guru SMP Shalahuddin Malang pada tahap penulisan adalah sebagai berikut.

Dari 24 guru peserta pelatihan, hingga hari terakhir jadwal pengumpulan artikel hanya 19 guru yang mengumpulkan hasil tulisannya. Berikut hasil analisis dari hasil tulisan guru pada setiap sistematika artikel ilmiah berbasis PTK.

\section{Judul}

Kriteria judul artikel ilmiah berbasis PTK adalah informatif, menggambarkan variabelvariabel penelitian, tidak secara detail menggambarkan lokasi penelitian, dan berjumlah maksimal 15 kata (Modul Pelatihan, 2015:20). Berdasarkan kriteria tersebut, judul artikel ilmiah 18 guru sudah memenuhi kriteria tersebut dan 1 guru belum sesuai kaidah tersebut.

\section{Nama Penulis}

Sesuai dengan kaidah, dalam artikel ilmiah berbasis PTK (Modul Pelatihan, 
2015:20), nama penulis ditulis tanpa disertai gelar. Nama lembaga ditulis sebagai catatan kaki di halaman pertama. Jika lebih dari satu penulis, nama penulis kedua diletakkan di catatan kaki. Dari hasil analisis terhadap 19 artikel ilmiah guru, seluruhnya telah menuliskan nama penulis dan lembaga dengan tepat.

\section{Abstrak \\ Sesuai dengan kaidah di Modul Pelatihan (2015:20) bahwa abstrak berisi pernyataan ringkas memuat masalah, tujuan, prosedur, dan hasil penelitian. Panjang antara $50-75$ kata (atau tidak lebih dari setengah halaman), ditulis dalam 1 paragraf, spasi 1 , dan menjorok $1,2 \mathrm{~cm}$ dari paragraf luar tulisan. Dari hasil analisis terhadap 19 artikel ilmiah guru, 11 di antaranya sudah sesuai dengan kaidah, sedangkan 8 sisanya belum sesuai kaidah.}

\section{Kata Kunci}

Kata kunci dalam artikel ilmiah penelitian umumnya berisi kata pokok yang menggambarkan daerah masalah yang diteliti. Untuk itu, jumlahnya dibatasi sekitar 3-5 kata saja (Modul Pelatihan, 2015:20). Setelah diidentifikasi, 12 guru sudah tepat menuliskan kata kunci, sedangkan 7 lainnya masih kurang tepat. Jika ditinjau dari teknik penulisannya, seluruh kata kunci di atas sudah sesuai kaidah (Modul Pelatihan, 2015:20) yaitu jumlahnya tidak lebih dari 5 kata. Namun, ditinjau dari isinya, kata kunci urutan kedua dan ketiga belum sesuai dengan kaidah.

\section{Pendahuluan}

Ditinjau dari isinya, pendahuluan artike ilmiah berbasis PTK hendaknya berisi latar belakang, masalah dan wawasan rencana pemecahan masalah, rumusan tujuan, serta manfaat penelitian. Adapun secara teknis, penulisannya tidak menggunakan judul subbab atau paragraf pendahuluan langsung ditulis di bawah kata kunci (Modul Pelatihan, 2015:20). Menurut hasil identifikasi, diketahui bahwa 6 artikel ilmiah guru sudah sesuai dengan kaidah dan 13 lainnya belum sesuai dengan kaidah. Ketidaksesuaian dengan kaidah tersebut pada umumnya disebabkan oleh dalam pendahuluan hanya terdapat hasil analisis masalah, wawasan pemecahan masalah, dan rumusan masalah saja. Namun, di dalam pendahuluan tersebut tidak ada latar belakang, tujuan, dan manfaat penelitian. Latar belakang yang dimaksud di sini adalah hubungan antara masalah, sumber masalah, metode pembelajaran yang diterapkan, dan urgensitas penelitian.

\section{Metode}

Metode penelitian berisi rancangan penelitian, data, sumber data, prosedur pengumpulan data, analisis data, pengecekan keabsahan data. Dari segi teknis, penulisannya diawali dengan judul subbab (Modul Pelatihan, 2015:20). Hasil identifikasi tim terhadap artikel ilmiah guru menunjukkan hanya 5 guru yang menulis metode penelitian dengan lengkap di artikel ilmiahnya. Sementara 14 guru kurang lengkap. Yang membuat kurang lengkap pada umumnya disebabkan oleh metode penelitian hanya terdiri atas rancangan penelitian, data, sumber data, dan prosedur pengumpulan data saja. Adapun prosedur pengumpulan data yang berbasis PTK, analisis data, dan pengecekan keabsahan data tidak ada.

\section{Hasil}

Menurut rubrik penyuntingan artikel ilmiah berbasis PTK (Modul Pelatihan, 2015:20), bab hasil berisi tentang hasil analisis data terkait dengan fokus penelitian. Analisis data yang dimaksud adalah sesuai dengan rumusan masalah. Selain itu, dalam bab hasil ini harus tergambar proses dan hasil tindakan pada setiap siklus. Menurut hasil identifikasi terhadap artikel ilmiah guru, 14 telah mampu menulis hasil penelitian sesuai dengan kriteria di atas, sedangkan 4 sisanya belum sesuai. Dikatakan belum sesuai karena paparan hasil penelitian kurang detail dalam memaparkan proses tindakan pada setiap siklus. Paparan lebih memfokuskan pada hasil yang diperoleh. Akan tetapi, sebabsebab diperolehnya hasil tersebut kurang jelas.

\section{Pembahasan}

Pembahasan dalam artikel ilmiah berbasis PTK berisi jawaban rumusan masalah, ketercapaiannya, tafsiran temuan-temuan, dan menyusun teori baru/modifikasi teori yang ada (Modul Pelatihan, 2015:20). Setelah diidentifikasi tampak bahwa 19 guru masih belum mahir menguraikan bab pembahasan. Para guru terkesan hanya menceritakan kembali bab hasil dan menjawab rumusan masalah tanpa membuat penafsiran terhadap temuan hasil tindakan dan tidak mengaitkan hasil temuan tersebut dengan landasan teori sehingga tidak ada kegiatan dalam hal 
menyusun/memodifikasi teori berdasarkan hasil temuan.

\section{Simpulan}

Simpulan berisi pokok-pokok pikiran tentang esensi hasil dan pembahasan (Modul Pelatihan, 2015:20). Setelah dianalisis, 19 bab simpulan artikel ilmiah guru sudah memenuhi kriteria tersebut sehingga tampaknya guru tidak mengalami kendala dalam membuat bab simpulan.

\section{Saran}

Dari 19 artikel ilmiah berbasis PTK guru, setelah dilakukan penyuntingan pada bab saran, 16 di antaranya sesuai dengan komponen isi, sedangkan 3 di antaranya belum sesuai. Adapun komponen isi bab saran seharusnya mengandung tindakan praktis, pengembangan teoretis, dan penelitian Ianjutan (Modul Pelatihan, 2015:20). Ketiga bab saran guru dikatakan belum sesuai komponen isi karena hanya berisi tindakan praktis saja. Belum ada langkah pengembangan teoretis dan penelitian lanjutan.

\section{Daftar Rujukan}

Daftar rujukan berisi keterangan referensireferensi yang dikutip dalam artikel (Modul Pelatihan, 2015:20). Dari 19 artikel ilmiah yang terkumpul, setelah diidentifikasi bahwa guru tidak mengalami hambatan dalam menuliskannya. Hanya terkadang guru kurang teliti dalam mensinkronkan antara kutipan dengan daftar rujukan. Misalnya ketika di dalam artikel terdapat 6 kutipan, maka di bagian daftar rujukan hanya terdapat 4 daftar rujukan. Bahkan ada satu artikel ilmiah yang mengopi seluruh daftar rujukan dari contoh PTK yang diberikan tim. Padahal di dalam artikel ilmiahnya, tidak seluruh rujukan tersebut dikutip.

\section{Aspek Kebahasaan}

Aspek kebahasaan yang dinilai dalam penulisan artikel ilmiah meliputi koherensi isi artikel dan penggunaan bahasa Indonesia ragam ilmiah (Modul Pelatihan, 2015:20). Berdasarkan analisis, diketahui bahwa 19 artikel ilmiah guru telah memiliki koherensi isi antarbagian. Namun, dari segi penggunaan bahasa Indonesia ragam ilmiah, masih terdapat banyak kesalahan pemilihan diksi, ejaan, dan tanda baca.

\section{Proses Pelatihan Penulisan Artikel IImiah Berbasis Penelitian Tindakan Kelas pada Guru SMP Shalahuddin Malang pada Tahap Penyuntingan}

Adapun kegiatan penyuntingan dilakukan oleh tim melalui email setelah para guru mengirimkan hasil tulisannya maksimal satu minggu setelah pelatihan. Berikut hasil penyuntingan terhadap hasil tulisan guru pada setiap sistematika artikel ilmiah berbasis PTK.

\section{Judul}

Hasil penyuntingan terhadap judul artikel ilmiah guru menunjukkan 18 guru sudah memenuhi kaidah judul artikel ilmiah berbasis PTK dan 1 guru belum sesuai.

\section{Nama Penulis}

Dari hasil analisis terhadap 19 artikel ilmiah guru, seluruhnya telah menuliskan nama penulis dan lembaga dengan tepat yaitu nama ditulis tanpa gelar dan nama lembaga diletakkan di catatan kaki. Hal ini sesuai dengan kaidah penulisan nama penulis dan lembaga dalam sebuah artikel ilmiah berbasis PTK di Modul Pelatihan halaman 20.

\section{Abstrak}

Dari hasil analisis terhadap 19 artikel ilmiah guru, 11 di antaranya sudah sesuai dengan kaidah, sedangkan 8 sisanya belum sesuai kaidah. Berikut dua abstrak yang kurang sesuai kaidah.

\section{Kata Kunci}

Setelah diidentifikasi, 12 guru sudah tepat menuliskan kata kunci, sedangkan 7 lainnya masih kurang tepat. Berikut ini sebagian kata kunci yang kurang memenuhi kaidah artikel ilmiah.

\section{Pendahuluan}

Menurut hasil identifikasi, diketahui bahwa 6 artikel ilmiah guru sudah sesuai dengan kaidah dan 13 lainnya belum sesuai dengan kaidah. Ketidaksesuaian dengan kaidah tersebut pada umumnya disebabkan oleh dalam pendahuluan hanya terdapat hasil analisis masalah, wawasan pemecahan masalah, dan rumusan masalah saja. Namun, di dalam pendahuluan tersebut tidak ada latar belakang, tujuan, dan manfaat penelitian. 


\section{Metode}

Hasil identifikasi tim terhadap artikel ilmiah guru menunjukkan hanya 5 guru yang menulis metode penelitian dengan lengkap di artikel ilmiahnya. Sementara 14 guru kurang lengkap. Hal itu disebabkan oleh pada umumnya di dalam metode penelitian tidak terdapat prosedur pengumpulan data yang berbasis PTK, analisis data, dan pengecekan keabsahan data.

\section{Hasil}

Menurut hasil identifikasi terhadap artikel ilmiah guru, 14 telah mampu menulis hasil penelitian sesuai dengan kriteria, sedangkan 4 sisanya belum sesuai. Dikatakan belum sesuai karena paparan lebih memfokuskan pada hasil yang diperoleh, sedangkan sebabsebab diperolehnya hasil tersebut kurang jelas.

\section{Pembahasan}

Berdasarkan hasil identifikasi dan penyuntingan tim terhadap 19 bab pembahasan artikel ilmiah guru ditemukan bahwa seluruhnya belum mahir menguraikan bab tersebut. Para guru terkesan hanya menceritakan kembali bab hasil dan menjawab rumusan masalah, tanpa mengaitkan hasil temuan tersebut dengan landasan teori. Padahal menurut rubrik penyuntingan artikel ilmiah berbasis PTK, bab pembahasan berisi jawaban rumusan masalah, ketercapaiannya, tafsiran temuantemuan, dan menyusun teori baru/modifikasi teori yang ada.

\section{Simpulan}

Menurut hasil penyuntingan, bab simpulan artikel ilmiah 19 guru sudah sesuai dengan kaidah yaitu telah berisi pokok-pokok pikiran tentang esensi hasil dan pembahasan. Dengan demikian, dapat dikatakan bahwa guru tidak mengalami hambatan dalam menyusun bab simpulan.

\section{Saran}

Dari 19 artikel ilmiah berbasis PTK guru, setelah dilakukan penyuntingan pada bab saran, 16 di antaranya sesuai dengan komponen isi, sedangkan 3 di antaranya belum sesuai.

\section{Daftar Rujukan}

Setelah diidentifikasi 19 artikel ilmiah yang terkumpul, dapat dikatakan bahwa guru tidak mengalami hambatan dalam menuliskan daftar rujukan. Hanya terkadang guru kurang teliti dalam mensinkronkan antara kutipan dengan daftar rujukan. Misalnya ketika di dalam artikel terdapat 6 kutipan, maka di bagian daftar rujukan hanya terdapat 4 daftar rujukan. Bahkan ada satu artikel ilmiah yang mengopi seluruh daftar rujukan dari contoh PTK yang diberikan tim. Padahal di dalam artikel ilmiahnya, tidak seluruh rujukan tersebut dikutip.

\section{Aspek Kebahasaan}

Berdasarkan analisis, diketahui bahwa 19 artikel ilmiah guru telah memiliki koherensi isi antarbagian. Namun, dari segi penggunaan bahasa Indonesia ragam ilmiah, masih terdapat banyak kesalahan pemilihan diksi, ejaan, dan tanda baca.

\section{SIMPULAN DAN SARAN}

Berdasarkan hasil dan pembahasan pengabdian masyarakat tentang pelatihan penulisan artikel ilmiah berbasis PTK melalui penerapan model interogasi elaboratif pada guru SMP Shalahuddin Malang dapat disimpulkan sebagai berikut.

1. Pada tahap interogasi, 24 guru peserta pelatihan tidak mengalami kesulitan dalam mengidentifikasi sistematika, komponen isi, dan aspek kebahasaan artikel ilmiah berbasis PTK.

2. Pada tahap elaboratif, 24 guru peserta pelatihan tidak mengalami kendala dalam mengidentifikasi fakta dalam PTK. Hanya setelah dijelaskan konsep PTK, para guru tidak percaya diri dengan PTK yang pernah ditulisnya.

3. Pada tahap penulisan, para guru telah mahir menulis artikel ilmiah berbasis PTK pada bagian judul, abstrak, kata kunci, hasil penelitian, simpulan, saran, dan daftar rujukan. Namun, para guru masih mengalami hambatan pada bagian pendahuluan, metode, dan pembahasan.

4. Pada tahap penyuntingan, karena sebagian besar guru belum menyelesaikan artikel ilmiahnya, penyuntingan akhirnya dilakukan oleh tim. Hasilnya guru telah mahir menulis artikel ilmiah berbasis PTK pada bagian judul, abstrak, kata kunci, hasil penelitian, simpulan, saran, dan daftar rujukan. Namun, para guru masih mengalami hambatan pada bagian pendahuluan, metode, dan pembahasan. 
dua:

Saran yang diberikan tim pengabdian ada

1. Bagi guru, hendaknya setelah pelatihan ini terampil menulis artikel ilmiah berbasis PTK sehingga bermanfaat bagi perbaikan proses pembelajaran dan peningkatan profesionalitasnya.

2. Bagi sekolah, hendaknya selalu memotivasi guru untuk meningkatkan angka partisipasi guru dalam penulisan dan publikasi artikel ilmiah berbasis PTK.

\section{DAFTAR PUSTAKA}

Buehl, Doug. 2001. Classroom Strategies for Interactive Learning. New York: International Reading Association.

Byrne, Donn. 1984. Teaching Writing Skills: Handbook for Language Teachers. Singapore: Longman Group.

Coelho, Elizabeth, dkk. 1989. All Sides of the Issue: Activities for Cooperative Jigsaw Groups. London: Alemary Press.

Ginnis, Paul. 2008. Trik dan Taktik Mengajar: Strategi Meningkatkan Strategi Pengajaran di Kelas. Jakarta: PT Indeks.

Iskandar. 2009. Penelitian Tindakan Kelas. Ciputat: Gaung Persada Press.

Kuntarto, Ninik M., dan Hendar Putranto. 2015. 99 Cara Mudah Menulis Karya IImiah. Yogyakarta: Indopublika.
Lorch, Sue. 1984. Basic Writing a Practical Approach: Second Edition. Canada: Little Brown and Company.

Maimunah, Siti Annijat. 2007. Buku Pintar Bahasa Indonesia. Jakarta: Prestasi Pustaka Publisher.

Nurhadi, dkk. 2004. Pembelajaran Kontekstual dan Penerapannya dalam KBK. Malang: UM Press.

Permendikbud No.18 Tahun 2007 tentang Sertifikasi Guru dalam Jabatan.

Permeneg Pendayagunaan Aparatur Negara dan Reformasi Birokrasi No. 16 Tahun 2009 tentang Jabatan Fungsional Guru dan Angka Kreditnya.

Supriyadi. 2013. Menulis Karya IImiah dengan Pendekatan Konstruktivisme: Pembelajaran Menulis Karya IImiah yang Inovatif dan Konstruktif. Gorontalo: UNG Press.

Suroso. 2007. Classroom Action Research: Peningkatan Kemampuan Menulis Melalui Penelitian Tindakan Kelas. Yogyakarta: Pararaton Publishing

Suyanto, dan Asep, Jihad. 2014. Cara Cepat Belajar Menulis Karya IImiah. Yogyakarta: Multi Presindo. 